\title{
ON SIMPLE METHODS FOR UNSATURATED SOIL HYDRAULIC CONDUCTIVITY DETERMINATION
}

\author{
0.0.S. BACCHI \\ Centro de Energia Nuclear na Agricultura/USP - C.P. 96, CEP: 13400-970-Piracicaba,SP. \\ K. REICHARDT \\ Departamento de Ftsica e Meteorologia - ESALQ/USP - C.P. 9, CEP:13418-900-Piracicaba,SP.
}

\begin{abstract}
The simple methods of LIBARDI et al. (1980) and SISSON et al. (1980) for $K(\theta)$ estimation, although developed on completely different theoretical basis, are rigorously identical for the exponential hydraulic conductivity model. The unit gradient approximation used in these methods seems valid for practical purposes but is theoretically invalid.
\end{abstract}

Key Words: soil hydraulic conductivity, unit gradient.

\section{SOBRE METODOS SIMPLIFICADOS DE DETERMINACAO DA CONDUTIVIDADE HIDRAULICA DO SOLO}

RESUMO: Os métodos simplicados de LIBARDI et al (1980) e de SISSON et al (1980), para determinação da função $\mathbf{K}(\theta)$, apesar de serem desenvolvidos sobre bases teóricas completamente diferentes, são rigorosamente iguais para o modelo exponencial de condutividade hidráulica. A hipbtese do gradiente unitário utilizada nestes métodos parece ser válida apenas para efeito prático, mas não o sendo teoricamente.

Deacritorea: condutividade hidráulica do solo, gradiente unitário.

\section{INTRODUCTION}

The goals of this short note are to comment that although the unit gradient assumption can be used under certain limitations in practice for $K(\theta)$ determination, as successfully shown by LIBARDI et al. (1980) and SISSON et al. (1980), is an approximation without theoretical support. Another objetive is simply to show that the above mentioned methods are identical for exponential $\mathbf{K}(\theta)$ relations.

Many methods used for field determination of unsaturated soil hydraulic conductivity are based on experimental designs involving the drainage of previously saturated soil profiles, preventing soil surface evaporation and using the so called "unit gradient assumption". This assumption first introduced by DAVIDSON et al. (1969), has been used in several field methods (e.g. CHONG et al., 1979; LIBARDI et al., 1980; SISSON et al., 1980) and extensively discussed in the literature (e.g. AHUJA et al., 1988). The validity of this assumption though frequently questioned was formally presented as theoretically invalid by REICHARDT (1993). All hydraulic conductivity determination methods are essentially based on Darcy's equation, $K(\theta)$ values being calculated from water flux density, hydraulic gradient $(\partial \mathrm{H} / \partial \mathrm{Z})$ ratios. The unit gradient assumption implies that conductivities are numerically equal to flux densities. During internal drainage, soil water flux densities vary several orders of magnitude over short time periods, whereas hydraulic gradients vary very little over long periods of time. Therefore the limitations of the use of unit gradient assumption are, in practice, not serious, and minimal the more homogeneous the soil is and the closer to saturation calculations are made. The procedure to calculate $K(\theta)$ relations presented by HILLEL et al. (1972) clearly indicates the effect of $\partial \mathrm{H} / \partial \mathrm{Z}$. Gradients deviating 0.2 from unity would introduce errors of about $20 \%$ in $\mathbf{K}(\theta)$ calculations.

\footnotetext{
' Bolsista do CNPq
} 
TABLE 1 - Comparison of $\mathbf{K}$ calculations not assuming united gradient, $\mathbf{K}$ (HILLEL), and assuming unit gradient, $K$ (LIBARDI), for $z=135 \mathrm{~cm}$.

\begin{tabular}{cccccc}
\hline \hline Time & $\partial H / \partial z$ & $\theta$ & K(HILLEL) & K(LIBARDI) & $\Delta K^{*}$ \\
\hline day) & $\left(\mathrm{cm}^{\left.-\mathrm{cm}^{-1}\right)}\right.$ & $\left(\mathrm{cm}^{3} \mathrm{~cm}^{-3}\right)$ & \multicolumn{2}{c}{$\left(\mathrm{cm} \cdot\right.$ day $\left.^{-1}\right)$} & $\%$ \\
0 & 0,99 & 0.385 & 7.870 & 8.600 & 0.6 \\
0.1 & 0,92 & 0.344 & 1.430 & 1.420 & -0.9 \\
0.2 & 0.95 & 0.320 & 0.530 & 0.490 & -6.6 \\
0.5 & 1.00 & 0.298 & 0.210 & 0.190 & -11.5 \\
1 & 1.05 & 0.279 & 0.096 & 0.081 & -15.6 \\
1.5 & 1.02 & 0.269 & 0.064 & 0.052 & -17.6 \\
2 & 1.01 & 0.262 & 0.048 & 0.038 & -19.0 \\
3 & 0.99 & 0.253 & 0.033 & 0.026 & -20.8 \\
4 & 0.97 & 0.246 & 0.024 & 0.019 & -22.2 \\
5 & 0.96 & 0.242 & 0.021 & 0.016 & -22.9 \\
10 & 0.86 & 0.232 & 0.014 & 0.010 & -24.8 \\
15 & 0.78 & 0.226 & 0.011 & 0.008 & -25.9 \\
20 & 0.72 & 0.222 & 0.009 & 0.007 & -26.6 \\
30 & 0.62 & 0.214 & 0.006 & 0.005 & -28.1 \\
45 & 0,52 & 0.208 & 0.005 & 0.003 & -29.1 \\
\hline \hline
\end{tabular}

$\Delta \mathrm{K}=[\mathbf{K}$ (Libardi) $-\mathrm{K}(\mathrm{Hillel})] .100$

Since water flow is important in the very wet region of the soil profile, when gradients are close to unity, methods using the unit gradient assumption may yield accurate $K(\theta)$ values. For the appropriate application of these simplified methods it is therefore recommended that observations of $\theta$ in space and time during the internal drainage process should not be done over long time periods unless hydraulic gradients are also monitored in order to observe deviations from unity.

When comparing methods, differences in $\mathrm{K}$ values are not only due to $\partial \mathrm{H} / \partial \mathrm{Z}$ estimates, and the evaluation of the limitations of the unit gradient assumption becomes difficult. As an illustration, Table 1 presents data of an internal drainage test, performed on a fairly homogeneous Haplustox soil profile (sandy yellow-red latosol) of the Piracicaba County, SP, Brazil, showing the evolution in time of $\partial H / \partial Z, \theta$ and $K$ values, calculated using measured values of $\partial \mathrm{H} / \partial \mathrm{z}$, according to HILLEL et al. (1972), and $K$ values assuming unit gradient, according to LIBARDI et al. (1980). It can be seen that $\partial \mathrm{H} / \partial \mathrm{z}$ oscilates around 1 up to about 5 days, from there on decreasing consistently. Although $\partial \mathrm{H} / \partial \mathrm{z}$ is approximately 1 over the period of 5 days, $\Delta K$ values indicate that $K$ values calculated by HILLEL et al. (1972) and LIBARDI et al. (1980) deviate consistently over time.

BACCHI \& REICHARDT (1991) analysed the simplified methods of LIBARDI et al. (1980) and SISSON et al. (1980) and showed that although developed on completely different theoretical basis they are rigorously identical. Applying the same exponential model used by LIBARDI et al (1980) for $K(\theta)$ in SISSON's formulation, the authors derived the following equation relating the soil water content $\theta\left(\mathrm{cm}^{3} \cdot \mathrm{cm}^{-3}\right)$ and the time of drainage $t$ (day):

LIBARDI et al. (1980) expresses the same relation by the following equation: 


$$
\begin{aligned}
& \theta_{0}-\theta=1 / \beta \ln \frac{\beta K_{0}}{z}+1 / \beta \ln t \\
& \theta_{0}-\theta=1 / \beta \ln \frac{\beta K_{0}}{a . z}+1 / \beta \ln t
\end{aligned}
$$

where $\mathrm{z}=$ depth $(\mathrm{cm})$, positive downwards; $\theta_{0}$ $\left(\mathrm{cm}^{3} \cdot \mathrm{cm}^{-3}\right)$ and $\mathrm{K}_{0}\left(\mathrm{~cm} . \mathrm{day}^{-1}\right)$ the values of $\theta$ and $\mathrm{K}$ during steady-state infiltration; a a parameter relating $\theta$ at a given depth $z$ to the average $\theta$ over the interval 0 to $\mathrm{z}$ and $\beta$ a dimensionless coefficient of the exponential $K(\theta)$ relation.

TABLE 2. Estimates of Ko (cm.day $y^{-1}$ ) and $\gamma$, for an Haplustox soil profile calculated through linear regressions of (1) and

\begin{tabular}{|c|c|c|c|c|}
\hline \multirow{2}{*}{$\begin{array}{l}\text { Depth } \\
\mathrm{z}(\mathrm{cm})\end{array}$} & \multicolumn{2}{|c|}{$K$} & \multicolumn{2}{|c|}{ B } \\
\hline & Ml & $\mathbf{M} 2$ & MI & $\mathrm{M} 2$ \\
\hline \multicolumn{5}{|c|}{ cm.day ${ }^{-1}$} \\
\hline 15 & 916,8 & 900.0 & 61.00 & 60.83 \\
\hline 13 & 69.6 & 69.6 & 56.02 & 55.96 \\
\hline 45 & 276,0 & 271,2 & 55.46 & 54.95 \\
\hline 60 & 144.0 & 172,8 & 43.27 & 43.16 \\
\hline 75 & 410,0 & 429,6 & 47.30 & 46.50 \\
\hline 90 & 427.2 & 410,2 & 48.76 & 47.71 \\
\hline 105 & 504,0 & 444.0 & 53.05 & 51.94 \\
\hline 120 & 307.2 . & 316,8 & 46.08 & 45,36 \\
\hline 135 & 206,4 & 223,2 & 43.96 & 43,45 \\
\hline
\end{tabular}
(2).

M1 = LIBARDI et al. (1980)

M2 = SISSON et al. (1980)

Although the approach of SISSON et al. (1980) also permits solutions for other than the exponential $K(\theta)$ model, and was extended to layered soils (SISSON, 1987), it is important to point to the fact that equations (1) and (2) are identical for $a=1$. For field soils, for which most likely a differs from unity, different results should be expected when using both methods. Although LIBARDI et al. (1980) combine the a value with $\theta$ and SISSON et al. (1980) with z, both are related to deviations from homogeneity.

Results obtained for the same sandy yellow-red latosol show the equivalence of the methods, as presented in Table 2.

\section{REFERENCES}

AHUJA, L.R.; BARNES, B.B.; CASSEL, D.K.; BRUCE, R.R.; NOFZIGER, D.L. Effect of assumed unit gradient during drainage on the determination of unsaturated conductivity and infiltration parameters. Soil Science, Baltimore, v.145, p.235-243, 1988.

BACCHI, O.O.S.; REICHARDT, K. Análise comparativa de dois métodos simplificados de determinação da condutividade hidráulica de solos. Revista Brasileira de Ciência do Solo, Campinas, v.15, p.249-252, 1991 .

CHONG, S.R.: GREEN, R.E.; AHUJA, L.R. Simple in situ determination of hydraulic conductivity by power function descriptions of drainage. Water Resources Research, Washington, v.17, p.11091114, 1979.

DAVIDSON. J.M.; STONE. L.R.; NIELSEN, D.R. LARUE, M.E. Field measurement and use of soil-water properties. Water Resources Research, Washington, v.5, p.1312-1321, 1969.

HILLEL, D.; KRENTOS, V.D.; STILIANOU, Y. Procedure and test of an internal drainage method for measuring soil hydraulic characteristics in situ. Soil Science, Baltimore, n.114, p.395-400. 1972.

LIBARDI, P.L.; REICHARDT, K.; NIELSEN, D.R. BIGGAR, J.W. Simple field methods for estimating soil hydraulic conductivity. Soil Science Society of America Journal, Madison, v.44, p.3-7. 1980

REICHARDT, $K$. Unit gradient in internal drainago experiments for the determination of soil hydraulic conductivity. Scientia Agricola, Piracicaba, v.50. n.1, p.151-153, 1993

SISSON, J.B. Drainage from layered field soils: fixed gradient models. Water Resources Research, Washington, v.23, p.2071-2075, 1987.

SISSON, J.B.; FERGUSON, A.H. van GENUCHTEN, M.Th. Simple method for predicting drainage from field plots. Soil Science Society of America Joumal, Madison, v.44, p.1147-1152, 1980.

Received May 15, 1993

Accepted May 25, 1993

Trabalho enviado para publicação em 15.05.1993

Trabalho aceito para publicaçāo em 25.05.1993 